\title{
Optimization of extraction conditions of flavonoids from Houttuynia cordata Thumb leaves
}

Phung M. Phan, Phuc T. D. Nguyen, Phuc H. Nguyen, Vo T. T. Vo, \& Anh T. Vu*

Faculty of Chemical Engineering and Food Technology, Nong Lam University, Ho Chi Minh City, Vietnam

ARTICLE INFO
Research Paper
Received: February 26, 2021
Revised: April 01, 2021
Accepted: April 08, 2021
Keywords
Cellulase
Flavonoids
Houttuynia cordata Thumb
Response surface methodology
*Corresponding author
Vu Thuy Anh
Email: vuthuyanh@hcmuaf.edu.vn

\begin{abstract}
This study was conducted to investigate the application of cellulase enzyme in the extraction of flavonoids from Houttuynia cordata Thumb leaves and optimize the extraction conditions. Independent variables, including enzyme concentration $(25-100 \mathrm{\mu g} / \mathrm{mL})$, temperature $\left(30-50^{\circ} \mathrm{C}\right)$, time $(30-120 \mathrm{~min})$ and ratio of raw materials to enzyme $(1: 15-1: 30 \mathrm{~g} / \mathrm{mL})$, were investigated. Extraction conditions of flavonoids were designed according to Central Composite Design - Uniform Precision (CCD), a response surface methodology using a software JMP Pro version 13. The results indicated that the optimal extraction conditions were found to be enzyme concentration (78.0 $\mathrm{\mu g} / \mathrm{mL})$, temperature $\left(41^{\circ} \mathrm{C}\right)$, time $(90 \mathrm{~min})$, and the ratio of material to the enzyme $(1: 26 \mathrm{~g} / \mathrm{mL})$. Under such conditions, the highest content of flavonoids $(24.04 \pm 0.05 \mathrm{mg} / \mathrm{g}$, dry matter) was obtained and validated. It can be concluded that the flavonoids can be optimally extracted under the optimal extraction conditions with assistance of cellulase.
\end{abstract}

Cited as: Phan, P. M., Nguyen, P. T. D., Nguyen, P. H., Vo, V. T. T., \& Vu, A. T. (2021). Optimization of extraction conditions of flavonoids from Houttuynia cordata Thumb leaves. The Journal of Agriculture and Development 20(2), 51-61. 


\title{
Tối ưu hoá điều kiện trích ly flavonoids từ lá diếp cá
}

\author{
Phan Minh Phụng, Nguyễn Thị Diễm Phúc, Nguyễn Hữu Phúc, \\ Võ Thị Tường Vi \& Vũ Thùy Anh*
}

Khoa Công Nghệ Hóa Học và Thực Phẩm, Trường Đại Học Nông Lâm TP.HCM, TP. Hồ Chí Minh

\author{
THÔNG TIN BÀI BÁO \\ Bài báo khoa học \\ Ngày nhận: 26/02/2021 \\ Ngày chỉnh sửa: 01/04/2021 \\ Ngày chấp nhận: 08/04/2021

\section{Từ khóa} \\ Diếp cá \\ Enzyme cellulase \\ Flavonoid \\ Phương pháp bề mặt đáp ứng \\ *Tác giả liên hệ \\ Vũ Thùy Anh \\ Email: vuthuyanh@hcmuaf.edu.vn
}

\section{TÓM TẮT}

Mục tiêu của nghiên cứu này nhằm sử dụng enzyme cellulase trong quá trình trích ly flavonoids từ lá diếp cá (Houttuynia cordata Thumb) và tối ưu hóa các yếu tố ảnh hưởng đến hiệu suất trích ly. Các thông số được khảo sát bao gồm: nồng độ enzyme (25 - 100 $\mu \mathrm{g} / \mathrm{mL})$, nhiệt độ $\left(30-50^{\circ} \mathrm{C}\right)$, thời gian $(30-120$ phút) và tỉ lệ giữa nguyên liệu: enzyme $(1: 15-1: 30 \mathrm{~g} / \mathrm{mL})$. Điều kiện trích ly flavonoids được tối ưu điều với thiết kế kiểu CCD (Central Composite Design) bằng phương pháp bề mặt đáp ứng, sử dụng phần mềm JMP Pro 13. Kết quả nghiên cứu đã xác định được điều kiện tối ưu trích ly flavonoids từ lá diếp cá, bao gồm nồng độ enzyme $(78,0 \mu \mathrm{g} / \mathrm{mL})$, nhiệt độ $\left(41^{\circ} \mathrm{C}\right)$, thời gian (90 phút) và tỉ lệ nguyên liệu: enzyme $(1: 26 \mathrm{~g} / \mathrm{mL})$. Với điều kiện trích ly tối ưu này, hàm lượng flavonoid đạt được là $24,04 \pm 0,05 \mathrm{mg} / \mathrm{g}$, vật chất khô.

\section{1. Đặt Vấn Đề}

Diếp cá (Houttuynia cordata Thumb) là một loại cây thảo mộc, có mùi tanh của cá được trồng rất phổ biến ở Việt Nam và một số nước Châu Á. Hiện nay, diếp cá được trồng làm rau gia vị hoặc dùng làm vị thuốc quý cho nhiều bài thuốc dân gian chữa bệnh. Chiết xuất từ diếp cá đã được chứng minh có tác dụng chống lại các bệnh bao gồm ung thư, tiểu đường, các bệnh ngoài da và hội chứng hô hấp cấp tính nặng (Miyata \& ctv., 2010; Du \& ctv., 2012; Kumar \& ctv., 2014). Ngoài ra, các chiết xuất từ diếp cá cũng có khả năng kháng khuẩn và kháng vi rút như sốt xuất huyết (Sekita \& ctv., 2016; Li \& ctv., 2017; Verma \& ctv., 2017). Theo các kết quả nghiên cứu sơ bộ được công bố gần đây, trong $100 \mathrm{~g}$ rau diếp cá có chứa nước $(91,5 \%)$, protid $(2,9 \%)$, glucid $(2,7 \%)$, lipid $(0,5 \%)$, cellulose $(1,8 \%)$, calci $(0,3 \mathrm{mg})$, kali $(0,1 \mathrm{mg})$, tiền vitamin $\mathrm{A}(1,26 \mathrm{mg})$, và vitamin $\mathrm{C}$ (68mg). Hơn nữa, diếp cá là loại rau rất thường được sử dụng trong khẩu phần ăn hằng ngày và rất rẻ tiền. Đã có nhiều nghiên cứu về trích ly các hợp chất sinh học từ các loại thực vật như flavonoids (Meng \& ctv., 2006), polyphenols (Li \& ctv., 2014), alkaloids (Wang \& ctv., 2008), và essential oil (Djihane \& ctv., 2017). Vì thế, trích ly các hợp chất sinh học từ cây diếp cá là rất cần thiết và hữu ích cho việc sử dụng vào nhiều sản phẩm thực phẩm chức năng và dược phẩm.

Tuy nhiên, để thu nhận và ứng dụng các chất có hoạt tính sinh học, dặc biệt là flavonoids từ diếp cá, một vấn đề đặt ra đó là làm sao để tăng cao hiệu suất trích ly và thiết lập được điều kiện trích ly tối ưu. Trong số những phương pháp thì trích ly với sự phối hợp của enzyme đã đem lại nhiều hiệu quả cũng như thân thiện với môi trường (VergaraBarberán, 2015). Phương pháp bề mặt đáp ứng (RSM, Response Surface Methodology) với sự hỗ trợ của các phần mềm xử lý số liệu đã trở thành một công cư hữu ích giúp thực hiện nghiên cứu các quá trình tối ưu hóa đa nhân tố, nhằm tiết 
kiệm thời gian và chi phí (Myers \& Montgomery, 2002).

Vì thế, nghiên cứu này được thực hiện nhằm tối ưu hoá điều kiện trích ly flavonoids từ là diếp cá với sự hỗ trợ của enzyme bằng phương pháp bề mặt đáp ứng.

\section{Vật Liệu và Phương Pháp Nghiên Cứu}

\subsection{Vật liệu}

\subsubsection{Lá diếp cá}

Nguyên liệu lá diếp cá, được mua ở chợ Đầu mối Thủ Đức, Thành phố Thủ Đức, TP.HCM. Nguyên liệu sau khi thu mua được vận chuyển nhanh về phòng thí nghiệm (không quá 1 giờ) để tiến hành các xử lý tiếp theo. Lá diếp cá được rửa sạch, làm khô ở nhiệt độ phòng. Sau đó, các mẫu được sấy khô ở nhiệt độ $40^{\circ} \mathrm{C}$ đến khi độ ẩm đạt được $5-6 \%$, nghiền mịn và bảo quản trong bao kín được hút chân không.

\subsubsection{Hóa chất}

Các hoá chất sử dụng trong phân tích bao gồm ethanol 96\% (Trung Quốc), chất chuẩn Quercetin (Ấn Độ); enzyme cellulase (Ấn Độ); $\mathrm{CH}_{3} \mathrm{COOK}$ (Trung Quốc); và $\mathrm{AlCl}_{3}$ (Trung Quốc).

\subsection{Bố trí thí nghiệm}

\subsection{1. Ảnh hưởng của enzyme đến hàm lượng flavonoids}

Đối với mẫu ngâm và xử lý enzyme: Cân $3 \mathrm{~g}$ bột diếp cá cho vào Beaker $250 \mathrm{~mL}$, sau đó cho dung dịch enzyme cellulase vào bột diếp cá với nồng độ $100 \mu \mathrm{g} / \mathrm{mL}$ theo tî lệ $1 / 20(\mathrm{w} / \mathrm{v})$ trong 60 phút ở nhiệt độ $40^{\circ} \mathrm{C}$. Sau đó, tiến hành lọc qua giấy lọc Whatman và tiến hành xác định hàm lượng flavonoids tổng (TFC) của mẫu trích ly trong pha nước. Tiếp đến, phần bã được trích ly tiếp bằng dung môi ethanol $70 \%$ với tỉ lệ $1 / 30(\mathrm{w} / \mathrm{v})$ trong 3 giờ ở nhiệt độ $60^{\circ} \mathrm{C}$. Tiến hành lọc và xác định TFC của mẫu trích ly trong pha cồn. Hàm lượng TFC tổng là tổng hàm lượng của dịch trích ly trong nước và trong ethanol.

Đối với mẫu không xử lý enzyme: cân $3 \mathrm{~g}$ bột diếp cá cho vào Beaker $250 \mathrm{~mL}$, sau đó cho dung môi ethanol $70 \%$ vào để trích ly trong thời gian 3 giờ ở nhiệt độ $60^{\circ} \mathrm{C}$. Tiến hành lọc và xác định TFC.

\subsubsection{Thí nghiệm tối ưu hóa điều kiện trích ly}

Phương pháp bề mặt đáp ứng được lựa chọn để tối ưu hóa điều kiện trích ly flavonoids từ lá diếp cá dưới sự hỗ trợ của enzyme cellulase. Ba thông số quan trọng của quá trình trích ly được nghiên cứu bao gồm: Nồng độ $\left(\mathrm{X}_{1}\right)$, nhiệt độ $\left(\mathrm{X}_{1}\right)$ và tỉ lệ dung môi/nguyên liệu $\left(\mathrm{X}_{1}\right)$. Thí nghiệm được bố trí theo kiểu CCD-Uniform Precision và ma trận thí nghiệm được xây dựng bằng phần mềm JMP 13 Pro. Trong các nghiên cứu thăm dò, chúng tôi đã xác định được giá trị biên của các nhân tố trích ly như trình bày trong Bảng 1 . Trong số 20 thí nghiệm được tiến hành có 6 thí nghiệm ở tâm. Mô hình toán học mô tả ảnh hưởng của các biến độc lập đối với biến phụ thuộc có dạng hàm đa thức bậc hai có dạng tổng quát như sau:

$\mathrm{Y}_{\mathrm{i}}=\mathrm{a}_{0}+\mathrm{a}_{1} \mathrm{X}_{1}+\mathrm{a}_{2} \mathrm{X}_{2}+\mathrm{a}_{3} \mathrm{X}_{3}+\mathrm{a}_{11} \mathrm{X}_{1}^{2}+$ $a_{22} X_{2}^{2}+a_{33} X_{3}^{2}+a_{12} X_{1} X_{2}+a_{13} X_{1} X_{3}+a_{23} X_{2} X_{3}$

Trong đó: $\mathrm{Y}_{\mathrm{i}}$ đại diện cho biến phụ thuộc, là hàm lượng flavonoids tổng, $\mathrm{a}_{0}$ là hằng số, $\mathrm{a}_{\mathrm{i}}, \mathrm{a}_{\mathrm{ii}}$, $\mathrm{a}_{\mathrm{ij}}$ lần lượt là các hệ số bậc 1 , bậc 2 và sự tương tác. $\mathrm{X}_{\mathrm{i}}, \mathrm{X}_{\mathrm{j}}$ là mức độ của các biến độc lập.

Bảng 1. Ma trận bố trí thí nghiệm mã hóa các biến độc lập

\begin{tabular}{cccc}
\hline \multirow{2}{*}{ Yếu tố } & \multicolumn{3}{c}{ Mã hoá } \\
\cline { 2 - 4 } & -1 & 0 & +1 \\
\hline Nồng độ & 50 & 75 & 100 \\
$(\mathrm{X} 1, \mu \mathrm{g} / \mathrm{mL})$ & 30 & 40 & 50 \\
$\begin{array}{c}\text { Nhiệt độ } \\
\left(\mathrm{X}_{2},{ }^{\circ} \mathrm{C}\right)\end{array}$ & 20 & 25 & 30 \\
\hline $\begin{array}{c}\text { Tỉ lệ dung môi/nguyên liệu } \\
\left(\mathrm{X}_{3}, \mathrm{v} / \mathrm{w}\right)\end{array}$ & & & \\
\hline
\end{tabular}

\subsection{Phương pháp phân tích}

\subsubsection{Xây dựng đường chuẩn Quercetin}

Pha dung dịch quercetin $100 \mu \mathrm{g} / \mathrm{mL}$ trong cồn 80\%. Từ dung dịch chuẩn quercetin $100 \mu \mathrm{g} / \mathrm{mL}$ tiếp tục pha ra các dung dịch có nồng độ lần lượt là $75,50,35,25,12,5 \mu \mathrm{g} / \mathrm{mL}$. Ứng với mỗi nồng độ dung dịch pha loãng hút $0,5 \mathrm{~mL}$ cho vào ống nghiệm sau đó thêm vào $1,5 \mathrm{~mL}$ ethanol $95 \%, 0,1$ $\mathrm{mL} \mathrm{AlCl}_{3} 10 \%, 0,1 \mathrm{~mL} \mathrm{CH}_{3} \mathrm{COOK} 1 \mathrm{M}$ và 2,8 $\mathrm{mL}$ nước cất. Lắc đều để yên ở nhiệt độ phòng 30 phút. Đo màu ở bước sóng $415 \mathrm{~nm}$, mẫu trắng thực hiện tương tự nhưng thay $\mathrm{AlCl}_{3}$ bằng nước cất.

Từ kết quả ở Hình 1 cho thấy trong khoảng 
nồng độ khảo sát, độ hấp thu tăng tuyến tính theo giá trị của hàm lượng flavonoids ở bước sóng cực đại $415 \mathrm{~nm}$. Từ đó phương trình đường chuẩn flavonoids được xây dựng là $\mathrm{y}=0,0597 \mathrm{x}$ - 0,0146, với hệ số tương quan $\mathrm{R}^{2}=0,9994$.

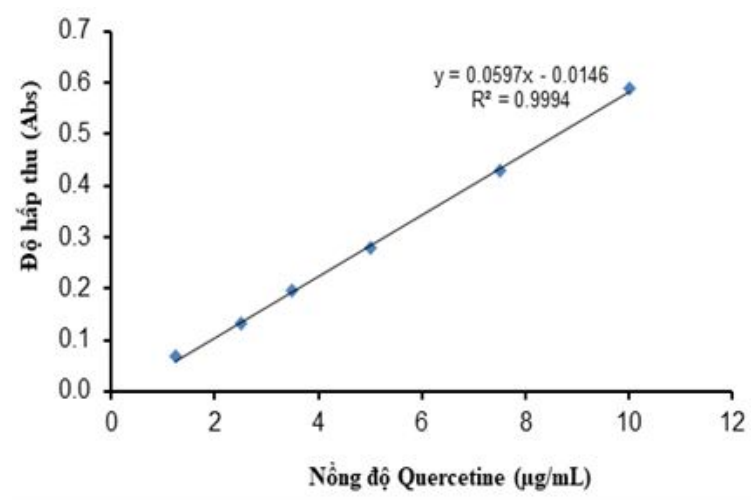

Hình 1. Đường chuẩn flavonoids tính theo tương đương quercetin.

\subsubsection{Xác định hàm lượng flavonoid tổng (TFC)}

Theo Chang \& ctv. (2001) flavonoids tổng được xác định theo phương pháp quang phổ theo nguyên tắc: Flavonoids tạo phức màu vàng với dung dịch $\mathrm{AlCl}_{3}$. Cường độ màu tỉ lệ thuận với hàm lượng flavonoids được xác định ở bước sóng $415 \mathrm{~nm}$. Quercetin được dùng làm chất chuần tham chiếu. Lấy $0,5 \mathrm{~mL}$ dịch chiết rau diếp đã được pha loãng thích hợp cho vào ống nghiệm sau đó thêm vào $1,5 \mathrm{~mL}$ ethanol $95 \%, 0,1 \mathrm{~mL} \mathrm{AlCl}_{3}$ $10 \%, 0,1 \mathrm{~mL} \mathrm{CH} \mathrm{CH}_{3} \mathrm{COOK} 1 \mathrm{M}$ và $2,8 \mathrm{~mL}$ nước cất. Lắc đều để yên ở nhiệt độ phòng 30 phút. Đo màu ở bước sóng $415 \mathrm{~nm}$. TFC trong mẫu được tính như sau:

$$
\mathrm{TFC}=\frac{\mathrm{a} \times \mathrm{V} \times \mathrm{n}}{\mathrm{m}} \times 10^{-3}(\mathrm{mg} / \mathrm{g}, \mathrm{vck})
$$

Trong đó:

a: hàm lượng flavonoid xác định từ đường chuẩn $(\mu \mathrm{g} / \mathrm{mL})$

$\mathrm{V}$ : tổng thể tích dịch chiết $(\mathrm{mL})$

n: hệ số pha loãng

m: khối lượng mẫu (g)

\subsection{Xử lí số liệu}

Các thí nghiệm được lặp lại 3 lần. Kết quả trình bày là giá trị trung bình \pm độ lệch chuẩn. Dữ liệu được kiểm tra bằng phần mềm Statgraphics Centurion XVI (Statgraphics Technologies, Inc.,
Virginia, USA). Phân tích phương sai (ANOVA) và chênh lệch ít có ý nghĩa nhất (LSD) được thực hiện so sánh giá trị trung bình ở mức 0,05 . Số liệu tối ưu được thiết kế và phân tích bằng phần mềm JMP Pro version 13.

\section{Kết Quả và Thảo Luận}

\section{1. Ảnh hưởng của enzyme đến hàm lượng flavonoids}

Kết quả thí nghiệm ảnh hưởng của enzyme cellulase đến hàm lượng TFC được thể hiện ở Hình 2. Kết quả xử lý thống kê cho thấy mẫu bột diếp cá khi trích ly flavonoid có sử dụng enzyme cellulase tăng đáng kể so với mẫu không có sự hỗ trợ của enzyme $(P<0,05)$. Cụ thể, hàm lượng TFC đạt được khoảng 10,68 (mg/g, vck) đối với mẫu có sự hỗ trợ của enzyme cellulase, trong khi hàm lượng này của mẫu không có sự hỗ trợ của enzyme (mẫu đối chứng) chỉ đạt khoảng $65 \%$ (6,98 mg/g, vck). Hay nói cách khác, hàm lượng flavonoid trong mẫu có xử lý enzyme cao gấp 1,53 lần so mẫu trích ly không sử dụng enzyme. Như vậy, sử dụng enzyme đã hỗ trợ tích cực đến đến hiệu suất trích ly flavonoids từ lá diếp cá, và được sử dụng cho các nghiên cứu tiếp theo.

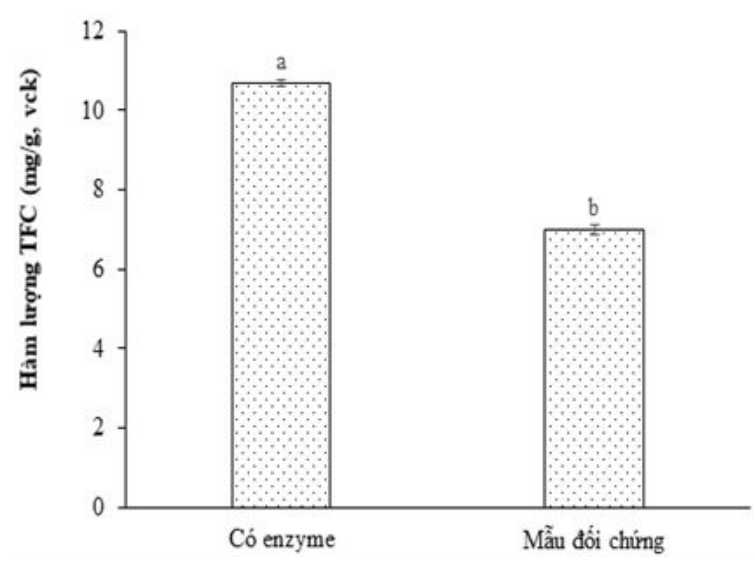

Hình 2. Ảnh hưởng của enzyme hàm lượng flavonoids thu được trong dịch trích ly. TFC: Hàm lượng flavonoid tổng.

\section{2. Ảnh hưởng của thời gian xử lý enzyme}

Dựa vào kết quả xứ lý thống kê và Hình 3 cho thấy ảnh hưởng của thời gian xử lý enzyme đến hàm lượng TFC tổng có ý nghĩa về mặt thống kê $(P<0,05)$. Khi tăng thời gian xử lý enzyme 
từ 30 phút đến 90 phút thì hàm lượng TFC tổng tăng từ 20,39 (mg/g, vck) đến 22,32 (mg/g, vck). Cụ thể, hàm lượng TFC tổng cao nhất là 22,32 (mg/g, vck) khi thời gian thuỷ phân 90 phút và thấp nhất là 20,39 (mg/g, vck) trong 30 phút. Tuy nhiên, khi tăng thời gian lên đến 120 phút thì hiệu suất thu hồi TFC tổng có khuynh hướng giảm. Vì sau khi xử lý enzyme đòi hỏi phải cần một khoảng thời gian nhất định để enzyme tiến hành phân cắt cellulose ở thành tế bào thực vật, tạo điều kiện cho dung môi dễ dàng khuếch tán và hòa tan các chất, sau đó khuếch tán ra bên ngoài góp phần làm tăng hiệu suất trích ly, sau đó thì hàm lượng TFC tổng không tăng nữa. Đồng thời, thời gian kéo dài sẽ hòa tan các chất không mong muốn làm ảnh hưởng đến quá trình trích ly (Hahn \& ctv., 2012; Hoang \& Le, 2020). Do vậy, thời gian thuỷ phân thích hợp là 90 phút và được cố định cho các thí nghiệm tiếp theo.

\section{3. Ảnh hưởng của nồng độ xử lý}

Hình 4 trình bày sự thay đổi của hàm lượng TFC tổng khi thay đổi nồng độ enzyme xử lý, từ nồng độ 25 đến $100 \mu \mathrm{g} / \mathrm{mL}$. Kết quả cho thấy nồng độ enzyme ảnh hưởng đến hàm lượng flavonoids tổng và có ý nghĩa về mặt thống kê $(P<0,05)$. Khi tăng nồng độ enzyme cellulase từ 25 đến $75 \mu \mathrm{g} / \mathrm{mL}$ thì hàm lượng $\mathrm{TFC}$ tổng tăng từ 19,38 đến 21,25 (mg/g, vck), nhưng khi tăng nồng enzyme đến $100 \mathrm{\mu g} / \mathrm{mL}$ thì hàm lượng TFC tăng không đáng kể. Hay nói cách khác, khi tăng nồng độ enzyme thì hàm lượng TFC tăng, tuy nhiên khi tăng nồng độ enzyme đến một mức nhất định thì hàm lượng TFC không tăng nữa và có khuynh hướng tiệm cận ngang. Nguyên nhân là do cơ chất trong mẫu nên hiệu suất phân cắt giảm, dẫn đến hiệu suất trích ly tăng không đáng kể (Puri \& ctv., 2012). Vì thế, khoảng nồng độ enzyme thích hợp cho trích ly flavonoids tổng từ lá diếp cá là từ 50 đến $100 \mu \mathrm{g} / \mathrm{mL}$ và được tiến hành tối ưu cho thí nghiệm tiếp theo.

\section{4. Ảnh hưởng của nhiệt độ xử lý}

Dựa vào kết quả Hình 5 cho thấy ảnh hưởng của nhiệt độ đến hàm lượng TFC toàn phần thu được là có ý nghĩa $(P<0,05)$. Khi tăng nhiệt độ từ $30^{\circ} \mathrm{C}$ dến $40^{\circ} \mathrm{C}$, hàm lượng TFC tăng từ 20,71 đến $21,54\left(\mathrm{mg} / \mathrm{g}\right.$, vck), khi tăng nhiệt độ tới $50^{\circ} \mathrm{C}$ thì hàm lượng TFC tăng không đáng kể $(P>$ $0,05)$. Nguyên nhân là vì enzyme là một phân tử sinh học có bản chất là protein, do đó nhiệt độ có ảnh hưởng rất lớn đến hoạt động xúc tác chuyển hóa cơ chất của enzyme; nếu nhiệt độ không đủ cao, trung tâm hoạt động của enzyme sẽ không thể hoạt động được tốt nhất và khả năng phân cắt mạch cellulose không đạt hiệu quả cao. Ngoài ra, nếu nhiệt độ cao sẽ phá hủy cấu trúc bậc 4 của enzyme gây bất hoạt và làm mất hoạt tính xúc tác của enzyme. Do enzyme có một khoảng nhiệt độ hoạt động tối ưu nhất định, thông thường ở nhiệt độ quá thấp (dưới $30^{\circ} \mathrm{C}$ ), hoạt lực của enzyme là thấp. Vì vậy, trong các thí nghiệm tối ưu tiếp theo khoảng nhiệt độ thích hợp cho hoạt động của enzyme được lựa chọn là 30 đến $50^{\circ} \mathrm{C}$ để đánh giá sự tương tác với các yếu tố khác.

\section{5. Ảnh hưởng của tỉ lệ nguyên liệu và dung môi}

Kết quả Hình 6 cho thấy tỉ lệ nguyên liệu và dung môi có ảnh hưởng có ý nghĩa thống kê dến hàm lượng TFC tổng trong dịch trích ly $(P$ $<0,05)$. Khi tăng tỉ lệ tăng từ 1:15 đến 1:30 (w/v) thì hàm lượng TFC tăng từ 20,67 dến 23,71 (mg/g, vck). Tỉ lệ nguyên liệu và dung môi tăng thì hàm lượng TFC tổng tăng, nhưng từ tî lệ 1:25 trở đi thì hàm lượng TFC tăng không đáng kể $(P$ $>0,05)$ và có khuynh hướng tiệm cận ngang. Bởi vì, khi tỉ lệ thể tích dung dịch enzyme cellulase tăng thì diện tích bề mặt tiếp xúc giữa enzyme và cơ chất càng lớn, khi tỉ lệ quá thấp thì enzyme không đủ tiếp xúc và tương tác với cơ chất làm giảm khả năng phân cắt mạch cellulase giảm (Truong \& ctv., 2015). Khi tỉ lệ thể tích quá cao, thì cơ chất và enzyme bị pha loãng, làm giảm khả năng thuỷ phân của enzyme, dẫn đến TFC thu được thấp. Từ kết quả này, tỉ lệ enzyme thích hợp cho thí nghiệm tối ưu hoá tiếp theo là 1:20 đến $1: 30(\mathrm{w} / \mathrm{v})$.

\subsection{Tối ưu hóa các điều kiện trích ly}

Từ các thí nghiệm đơn ở phía trên, các điều kiện trích ly với sự hỗ trợ enzyme cellulase, bao gồm nồng độ, nhiệt độ và tỉ lệ nguyên liệu: dung môi, được chọn cho nghiên cứu tối ưu điều kiện trích ly sao cho hàm lượng TFC thu được là cao nhất. Các khoảng thích hợp của các yếu tố này được trình bày ở Bảng 1 . Thí nghiệm tối ưu được thiết kế theo kiểu CCD bằng phương pháp RSM và kết quả hàm lượng TFC trong dịch trích ly khi thực hiện các thí nghiệm tối ưu được trình bày qua Bảng 2. Kết quả phân tích phương sai (ANOVA) đã xác định được mô hình đa thức bậc 


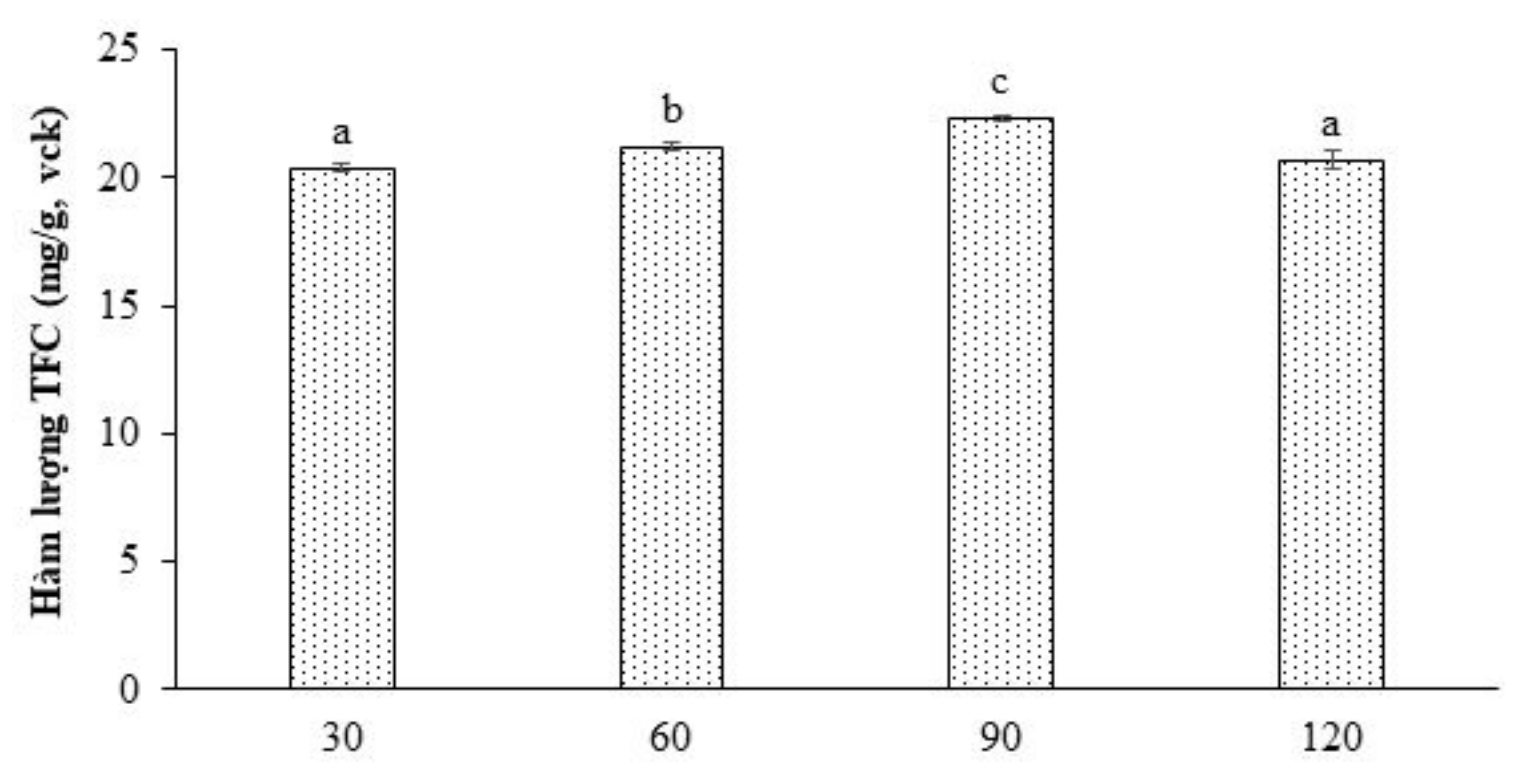

Thời gian (phút)

Hình 3. Ảnh hưởng của thời gian đến hàm lượng flavonoid tổng (TFC) toàn phần.

Các giá trị trung bình có ký tự khác nhau thể hiện sự khác biệt có ý nghĩa thống kê ở mức độ tin cậy $95 \%$.

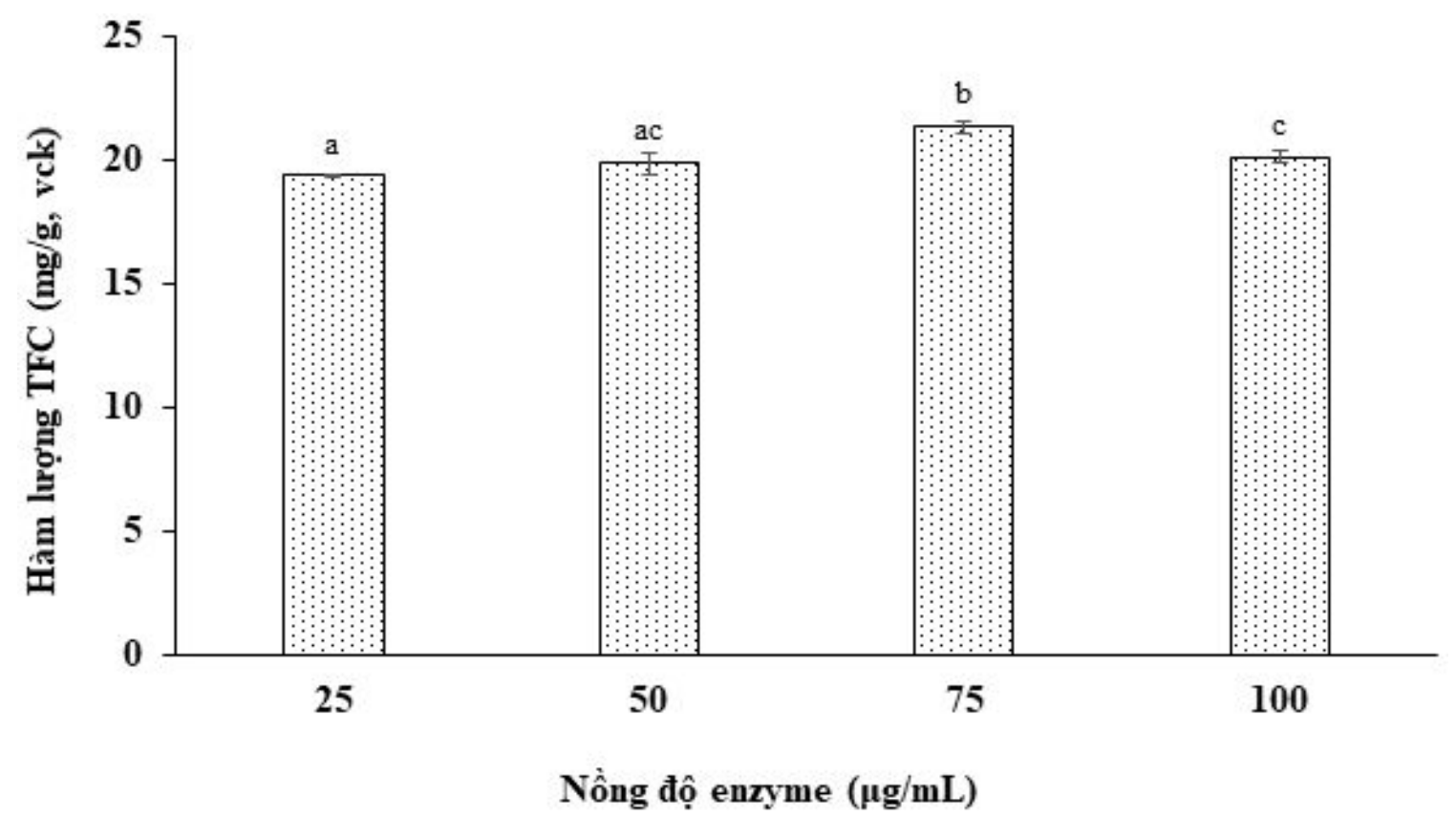

Hình 4. Ảnh hưởng của nồng độ enzyme Cellulase đến hàm lượng flavonoid tổng (TFC) toàn phần.

Các giá trị trung bình có ký tự khác nhau thể hiện sự khác biệt có ý nghĩa thống kê ở mức độ tin cậy $95 \%$.

2 có thể sử dụng để mô tả các số liệu thực nghiệm với hệ số $\mathrm{R}^{2}$ cao $(0,96)$. Các giá trị dự đoán tương đối phù hợp với các giá trị thực nghiệm thu dược từ thiết kế RSM (Bảng 2). Ngoài ra, kết quả xử lý ANOVA cho thấy mô hình hồi quy bậc 2 có ý nghĩa thống kê $(P<0,001)$. Do đó, có thể kết luận mô hình thu được có thể sử dụng để mô tả ảnh hưởng của các điều kiện trích ly (nồng độ, 


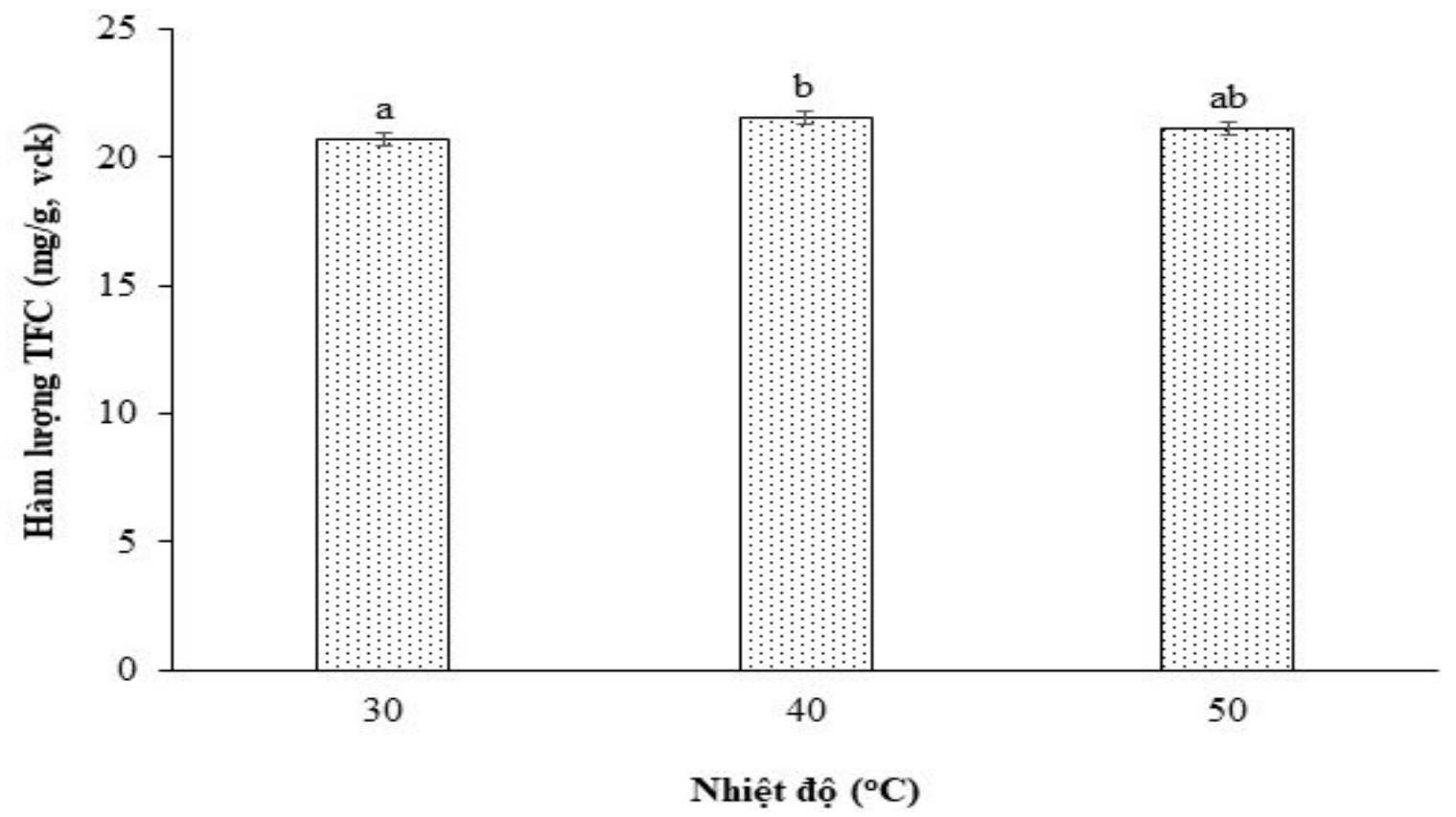

Hình 5. Ảnh hưởng của nhiệt độ đến hàm lượng flavonoid tổng (TFC) toàn phần.

Các giá trị trung bình có ký tự khác nhau thể hiện sự khác biệt có ý nghĩa thống kê ở mức độ tin cậy $95 \%$.

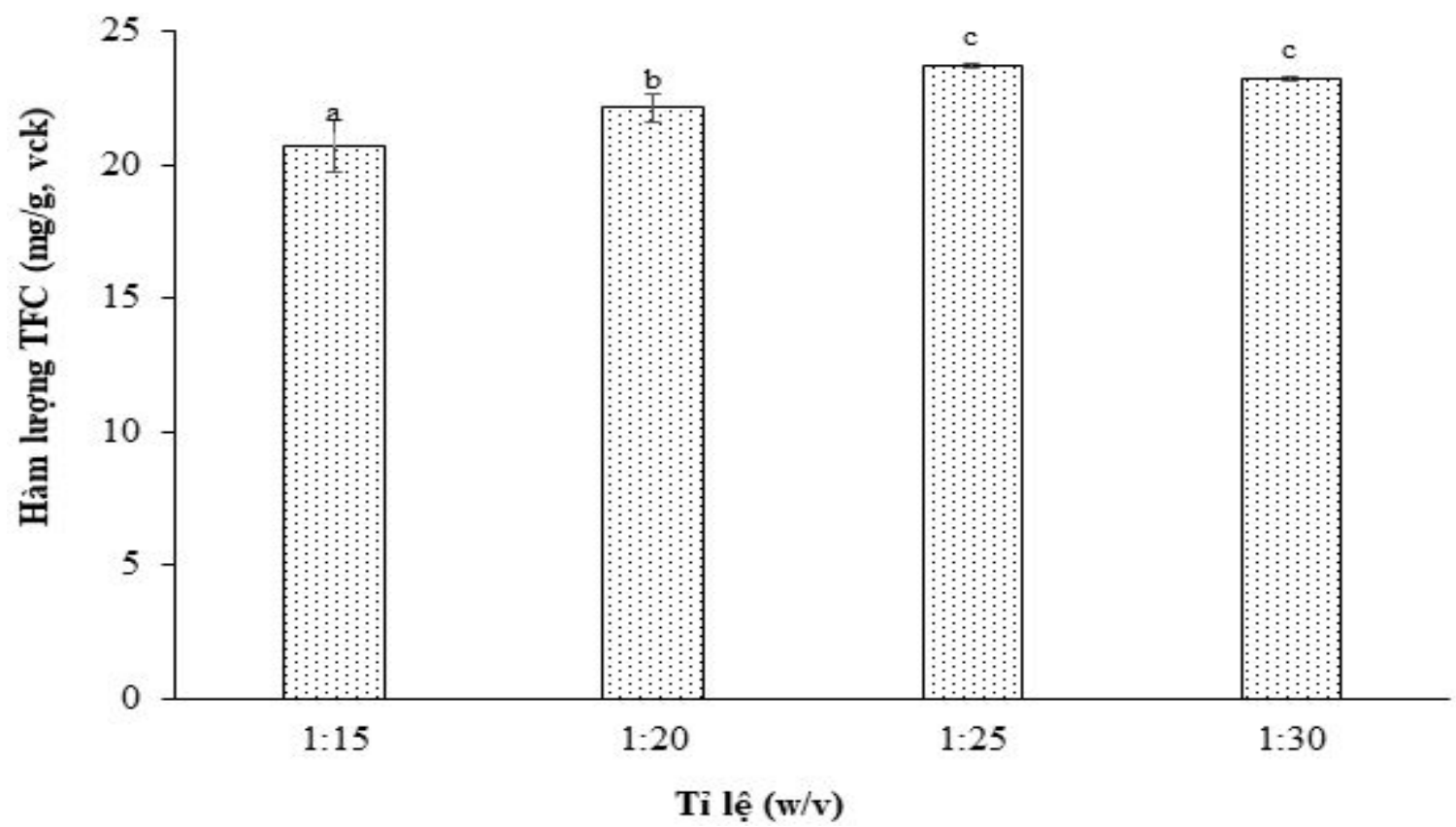

Hình 6. Ảnh hưởng của tỉ lệ nguyên liệu/dung môi đến hàm lượng flavonoid tổng (TFC) toàn phần.

Các giá trị trung bình có ký tự khác nhau thể hiện sự khác biệt có ý nghĩa thống kê ở mức độ tin cậy $95 \%$.

nhiệt độ và tỉ lệ nguyên liệu so với dung môi) đến hàm lượng flavonoids tổng trong dịch trích ly.

Ý nghĩa của các hệ số của mô hình đa thức bậc hai được xác định bằng cách sử dụng tî̉ lệ $\mathrm{t}(\mathrm{t}$ ratio) và giá trị $P$ (mức ý nghĩa) và được liệt kê trong Bảng 3. Giá trị tỉ lệ $\mathrm{t}$ lớn hơn và giá trị $P$ nhỏ hơn cho thấy ảnh hưởng đáng kể hơn đến các biến tương ứng (Amin \& Anggoro, 2004). Theo 
Bảng 2. Hàm lượng flavonoid tổng (TFC) theo thực nghiệm và dự đoán từ mô hình thiết kế

\begin{tabular}{cccccc}
\hline Thí nghiệm $^{\mathrm{a}}$ & $\begin{array}{c}\text { Nồng độ } \\
\left(\mathrm{X}_{1}, \mu \mathrm{\mu g} / \mathrm{mL}\right)\end{array}$ & $\begin{array}{c}\text { Nhiệt độ } \\
\left(\mathrm{X}_{2},{ }^{\circ} \mathrm{C}\right)\end{array}$ & $\begin{array}{c}\text { Tỉ lệ } \\
\left(\mathrm{X}_{3}, \mathrm{w} / \mathrm{v}\right)\end{array}$ & \multicolumn{2}{c}{ Hàm lượng TFC $(\mathrm{mg} / \mathrm{g}, \mathrm{vck})$} \\
\hline 1 & 75 & 40 & 30 & 22,89 & 23,06 \\
2 & 75 & 40 & 20 & 22,19 & 22,58 \\
3 & 50 & 50 & 30 & 21,18 & 20,85 \\
4 & 75 & 40 & 25 & 23,67 & 23,54 \\
5 & 75 & 40 & 25 & 23,74 & 23,54 \\
6 & 75 & 50 & 25 & 21,98 & 22,73 \\
7 & 50 & 40 & 25 & 22,01 & 22,19 \\
8 & 50 & 50 & 20 & 21,03 & 21,03 \\
9 & 100 & 50 & 20 & 20,60 & 20,17 \\
10 & 75 & 40 & 25 & 23,86 & 23,54 \\
11 & 100 & 30 & 30 & 21,65 & 21,51 \\
12 & 75 & 30 & 25 & 22,47 & 22,27 \\
13 & 75 & 40 & 25 & 23,72 & 23,54 \\
14 & 100 & 40 & 25 & 22,27 & 22,65 \\
15 & 75 & 40 & 25 & 23,70 & 23,54 \\
16 & 100 & 50 & 30 & 21,48 & 21,48 \\
17 & 50 & 30 & 20 & 20,22 & 20,08 \\
18 & 75 & 40 & 25 & 23,68 & 23,54 \\
19 & 50 & 30 & 30 & 19,45 & 19,74 \\
20 & 100 & 30 & 20 & 20,16 & 20,35 \\
\hline
\end{tabular}

${ }^{\mathrm{a}}$ Các thí nghiệm được thực hiện ngẫu nhiên .

kết quả Bảng 3, có thể thấy rằng yếu tố có ảnh hưởng lớn nhất đến hàm lượng TFC là hệ số bậc 2 của $\mathrm{X}_{1}$ (nồng độ) và $\mathrm{X}_{2}$ (nhiệt độ), kế đến là hệ số bậc 2 của $\mathrm{X}_{3}$ (tỉ lệ nguyên liệu so với dung môi) và hệ số tương tác của $\mathrm{X}_{1}$ và $\mathrm{X}_{3}$. Khi xét hệ số bậc 1 của phương trình hồi quy thì các yếu tố khảo sát không ảnh hưởng đáng kể đến hàm lượng TFC. Không có sự tương tác có ý nghĩa thống kê giữa yếu tố nồng độ và nhiệt độ, và nhiệt độ và tî̉ lệ $(P>0,05)$.

Để xác định mức tối ưu của các yếu tố độc lập đến $\mathrm{TFC}$ tổng, các đồ thị bề mặt $3 \mathrm{D}$ và đường đồng mức $2 \mathrm{D}$ đã được thể hiện ở Hình $7(\mathrm{a}, \mathrm{b}$, c). Đồ thị bề mặt đáp ứng cho thấy mối quan hệ giữa các yếu tố độc lập và flavonoids, trong khi đường đồng mức giúp hình dung hình dạng của bề mặt đáp ứng. Do đó, dựa vào các đồ thị giúp ích trong việc đánh giá sự phù hợp của mô hình (Baş \& Boyaci, 2007).

Hình $7 \mathrm{a}$ cho thấy ảnh hưởng của nồng độ và nhiệt độ đến hàm lượng TFC trong dịch trích ly. Nhìn chung, ở nhiệt độ cố đinh $\left(40^{\circ} \mathrm{C}\right)$, khi tăng nồng độ enzyme xử lý thì hàm lượng flavonoids tăng và đạt cực đại ở nồng độ khoảng $78 \mu \mathrm{g} / \mathrm{mL}$. Sau đó giảm dần khi tăng nồng độ enzyme xử lý. Ở nồng độ enzyme xử lý không đổi $(70$ gㅣ $/ \mathrm{mL})$,
Bảng 3. Hệ số hồi quy và tỉ lệ $\mathrm{t}$ ( $\mathrm{t}$ ratio) của phương trình tối ưu dự đoán hàm lượng flavonoid tổng (TFC)

\begin{tabular}{|c|c|c|}
\hline Hệ số hồi quy ${ }^{a}$ & & t ratio \\
\hline $\mathrm{a}_{0}$ & 23,543 & $<0,0001^{* * *}$ \\
\hline \multicolumn{3}{|l|}{ Bậc 1} \\
\hline $\mathrm{a}_{1}$ & 0,228 & 0,1051 \\
\hline $\mathrm{a}_{2}$ & 0,231 & 0,1007 \\
\hline $\mathrm{a}_{3}$ & 0,245 & 0,0846 \\
\hline \multicolumn{3}{|l|}{ Bậc 2} \\
\hline $\mathrm{a}_{11}$ & $-1,126$ & $0,0010^{* *}$ \\
\hline$a_{22}$ & - 1,042 & $0,0016^{* *}$ \\
\hline $\mathrm{a}_{33}$ & $-0,723$ & $0,0141^{*}$ \\
\hline \multicolumn{3}{|l|}{ Tương tác } \\
\hline $\mathrm{a}_{12}$ & $-0,284$ & 0,075 \\
\hline $\mathrm{a}_{13}$ & 0,37 & $0,0257^{*}$ \\
\hline $\mathrm{a}_{23}$ & 0,04 & 0,7931 \\
\hline $\mathrm{R}^{2}$ & 0,96 & \\
\hline
\end{tabular}

hàm lượng flavonoids tổng tăng khi nhiệt độ xử lý tăng và đạt cực đại ở nhiệt độ $41^{\circ} \mathrm{C}$, sau đó giảm dần khi tiếp tục tăng nhiệt độ xử lý. Khuynh hướng này cũng tương tự như thí nghiệm sơ bộ 


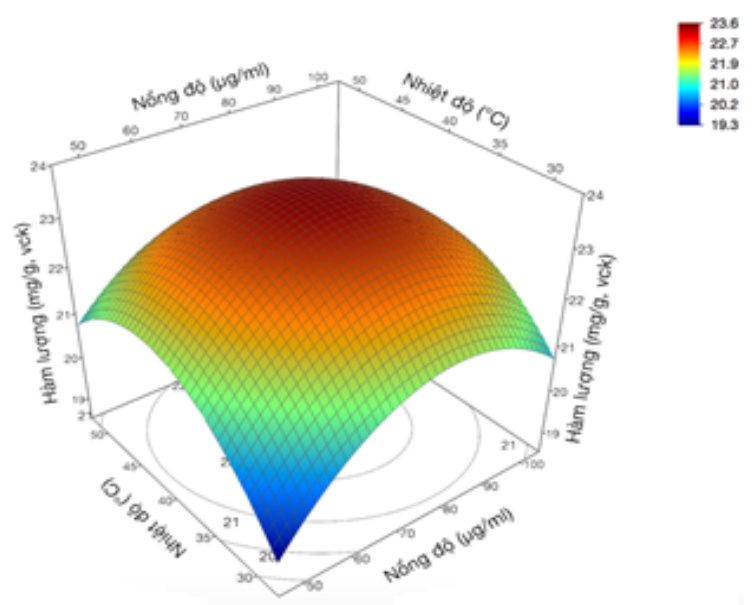

(a)

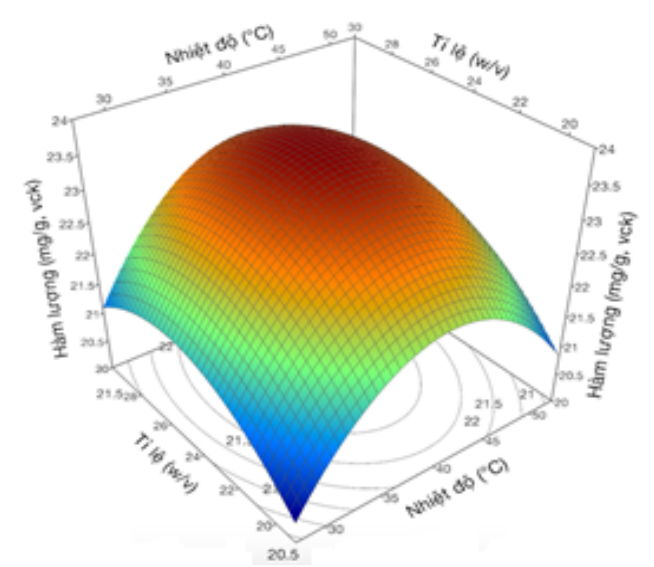

(b)

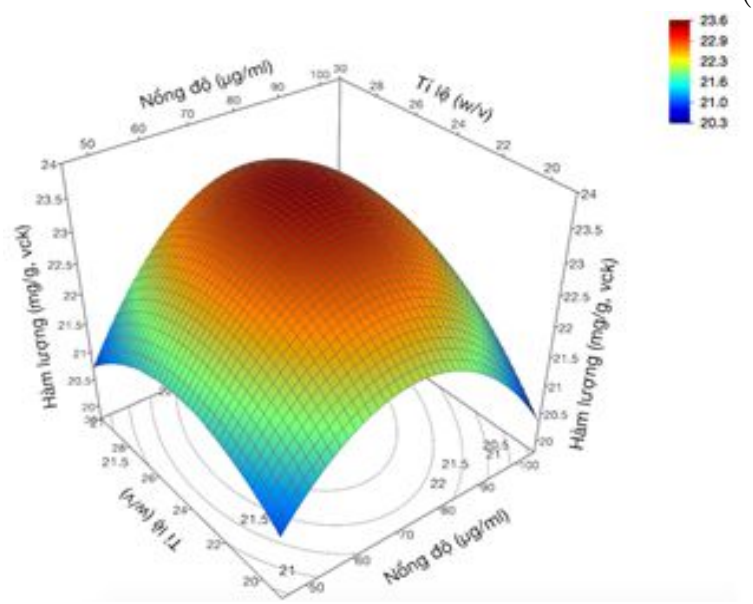

(c)

Hình 7. Bề mặt đáp ứng $3 \mathrm{D}$ và đường đồng mức $2 \mathrm{D}$ biểu diễn ảnh hưởng của các yếu tố (nồng độ, $\mathrm{X}_{1}$; nhiệt độ, $\mathrm{X}_{2}$ và tỉ lệ, $\mathrm{X}_{3}$ ) đến hàm lượng flavonoid tổng (TFC).

trước đó (Mục 3.3 và 3.4). Kết quả Bảng 3 , cho thấy không có sự tương tác có ý nghĩa thống kê giữa nồng độ và nhiệt độ xử lý $(P>0,05)$.

Kết quả Hình 7b cho thây, hàm lượng TFC tăng lên khi nhiệt độ xử lý tăng lên và đạt cực đại ở $41^{\circ} \mathrm{C}$ khi tỉ lệ giữa nguyên liệu và dung môi cố định ở mức $1: 25(\mathrm{w} / \mathrm{v})$. Ở nhiệt độ xử lý cố định nào đó, hàm lượng TFC đạt cực đại khi nhiệt độ xử lý là $41^{\circ} \mathrm{C}$. Ngoài ra, kết quả xử lý thống kê cho thấy không có sự tương tác giữa nhiệt độ xử lý và tỉ lệ giữa nguyên liệu và dung môi $(P>$ $0,05)$.

Kết quả xử lý thống kê (Bảng 3) và Hình $7 \mathrm{c}$ cho thâyy có sự tương tác giữa nồng độ enzyme xử lý và tỉ lệ giữa nguyên liệu và dung môi $(P<$ $0,05)$. Khuynh hướng ảnh hưởng hưởng của nồng độ và tỉ lệ cũng tương tự như Hình $7 \mathrm{a}$ và $7 \mathrm{c}$.
Mục tiêu của nghiên cứu này nhằm xác định các điều kiện trích ly tối ưu, do đó phương pháp tối ưu hoá đã được thực hiện bằng phần mềm JMP. Kết quả mô hình tối ưu là hàm lượng flavonoids tổng thu được cao nhất trong dịch trích ly. Kết quả Hình 8 cho thấy giá trị lý thuyết tối ưu của hàm lượng flavonoids tổng $(23,59 \mathrm{mg} / \mathrm{g}$, vck) đạt được trong điều kiện trích ly tối ưu là nồng độ $78 \mathrm{\mu g} / \mathrm{mL}$, nhiệt độ $41^{\circ} \mathrm{C}$ và tỉ lệ nguyên liệu so với dung môi là 1:26 (w/v).

Hơn nữa, việc so sánh giữa các giá trị đáp ứng được dự đoán và đo lường là một cách để thiết lập mức độ chính xác của mô hình mô tả quá trình trích ly được nghiên cứu. Do đó, một thí nghiệm (với ba lần lặp lại) đã được thực hiện ở các điều kiện tối ưu. Kết quả thống kê cho thấy không có khác biệt đáng kể giữa giá trị dự đoán 


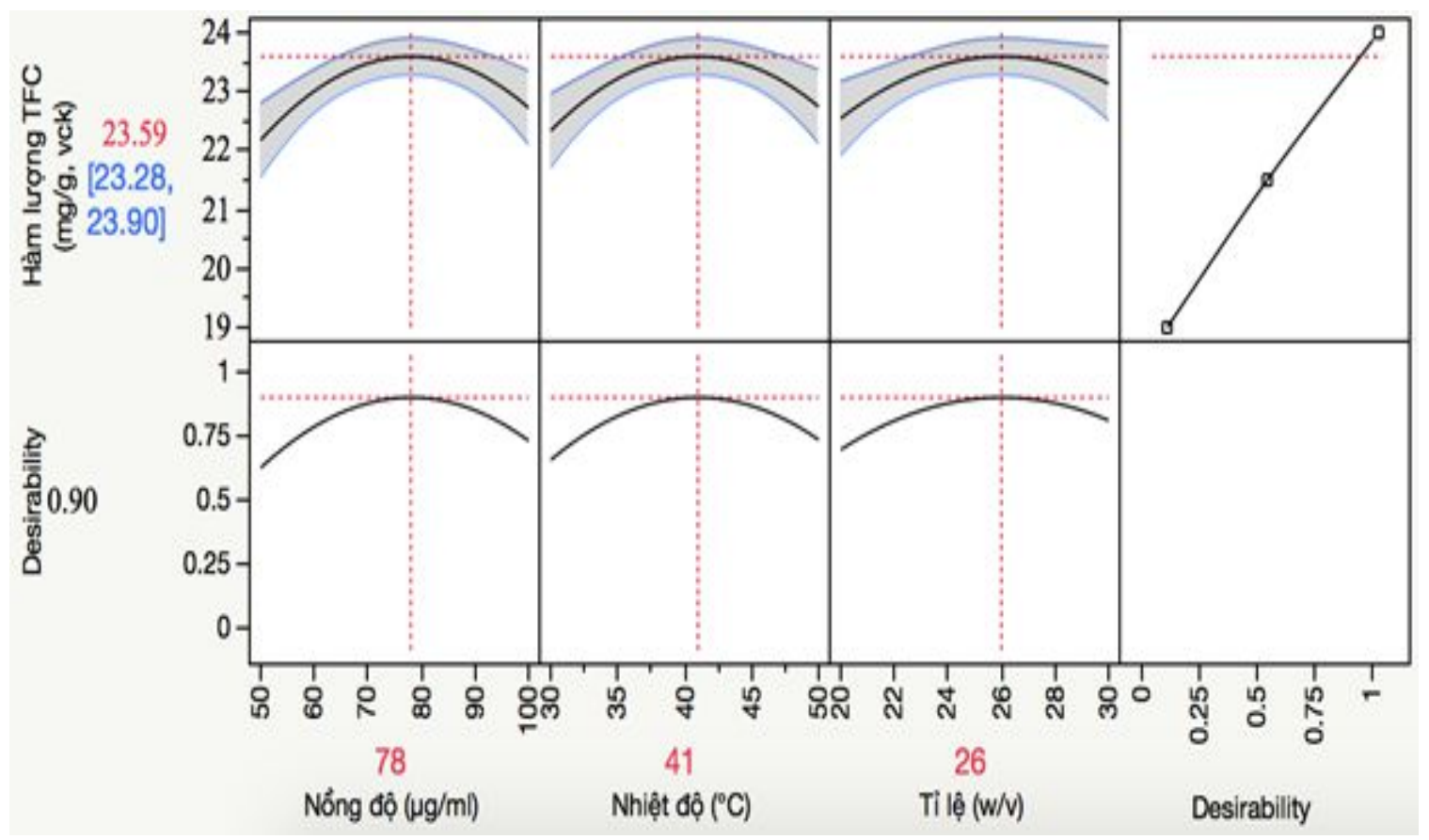

Hình 8. Mô hình dự đoán hàm lượng flavonoid tổng (TFC) là một hàm của nồng độ, nhiệt độ và tỉ lệ giữa nguyên liệu và dung môi.

và đo lường của hàm lượng TFC tổng. Hàm lượng flavonoids tổng của thí nghiệm thẩm tra đạt 24,04 $\pm 0,05(\mathrm{mg} / \mathrm{g}$, vck $)$. Điều này có thể thấy hàm lượng TFC đo được phù hợp với các giá trị được dự đoán bằng mô hình hồi quy bậc 2 . Như vậy, có thể sử dụng phương trình bậc hai để dự đoán hàm lượng flavonoids tổng trong các điều kiện trích ly tối ưu. Hay nói cách khác, phương pháp tối ưu hóa bề mặt đáp ứng đối với các điều kiện trích ly flavonoids từ lá diếp cá có giá trị thực tiễn.

\section{Kết Luận}

Quá trình trích ly flavonoids từ là diếp cá có hiệu quả khi sử dụng enzyme cellulase trong thời gian 90 phút. Nghiên cứu đã xây dựng được mô hình toán học mô tả ảnh hưởng của các yếu tố trích ly (nồng độ enzyme, nhiệt độ và tỉ lệ nguyên liệu/dung môi) đến hàm lượng flavonoids từ lá diếp cá. Các giá trị tối ưu để chiết từ lá diếp cá như sau: nồng độ enzyme $78 \mu \mathrm{g} / \mathrm{mL}$, nhiệt độ $41^{\circ} \mathrm{C}$ và tỉ lệ nguyên liệu : enzyme là $1: 26 \mathrm{~g} / \mathrm{mL}$. Tại điều kiện trích ly tối ưu, hàm lượng flavonoids thu được là $24,04 \mathrm{mg} / \mathrm{g}$ vật chất khô. Từ kết quả này có thể khẳng định tiềm năng sử dụng lá diếp cá như một nguồn chiết xuất flavonoids tự nhiên với hiệu suất cao để nâng cao khả năng ứng dụng trong lĩnh vực thực phẩm chức năng và dược phẩm.

\section{Lời Cam Đoan}

Nhóm tác giả tuyên bố không có bất kỳ mâu thuẫn nào giữa các tác giả.

\section{Tài Liệu Tham Khảo (References)}

Amin, N. A. S., \& Anggoro, D. D. (2004). Optimization of direct conversion of methane to liquid fuels over cu loaded w/zsm-5 catalyst. Fuel 83(4-5), 487-494.

Baş, D., \& Boyaci, I. H. (2007). Modeling and optimization i: usability of response surface methodology. Journal of Food Engineering 78(3), 836-845.

Chang, J. S., Chiang, L. C., Chen, C. C., Liu, L. T., Wang, K. C., \& Lin, C. C. (2001). Antileukemic Activity of Bidens pilosa L. var. Minor (Blume) Sherff and Houttuynia cordata Thunb. The American Journal of Chinese Medicine 29(02), 303-312.

Djihane, B., Wafa, N., Elkhamssa, S., Pedro, D. H. J., Maria, A. E., \& Mohamed Mihoub, Z., (2017). Chemical constituents of Helichrysum italicum (Roth) G. Don essential oil and their antimicrobial activity against gram-positive and gram-negative bacteria, filamentous fungi and Candida albicans. Saudi Pharmaceutical Journal 25(5), 780-787. 
Du, S., Li, H., Cui, Y., Yang, L., Wu, J., Huang, H., Chen, Y., Huang, W., Zhang, R., Yang, J., Chen, D., Li, Y., Zhang, S., Zhou, J., Wei, Z., \& Chow, N. T. (2012). Houttuynia cordata inhibits lipopolysaccharide-induced rapid pulmonary fibrosis by up-regulating IFN- $\gamma$ and inhibiting the TGF$\beta 1 /$ Smad pathway. International Immunopharmacology 13(3), 331-340.

Hahn, T., Lang, S., Ulber, R., \& Muffler, K. (2012). Novel procedures for the extraction of fucoidan from brown algae. Process Biochemistry 47(12), 1691-1698.

Hoang, N. T. N., \& Le, T. T. T. (2020). Study on the influence of cellulase enzyme and microwave on the extraction of Flucoidan from the seaweed Ceratophyllum Submersum. Journal of Science and Technology-The University of Danang 18(3), 5-9.

Kumar, M., Prasad, S. K., Krishnamurthy, S., \& Hemalatha, S. (2014). Antihyperglycemic activity of Houttuynia cordata Thunb. in streptozotocin-induced diabetic rats. Advances in Pharmacological and Pharmaceutical Sciences 2014, 809438.

Li, A. N., Li, S., Zhang, Y. J., Xu, X. R., Chen, Y. M., \& Li, H. B. (2014). Resources and biological activities of natural polyphenols. Nutrients 6(12), 6020-6047.

Li, T., Liu, L., Wu, H., Chen, S., Zhu, Q., Gao, H., Yu, X., Wang, Y., Su, W., Yao, X., \& Peng, T. (2017). Antiherpes simplex virus type 1 activity of Houttuynoid A, a flavonoid from Houttuynia cordata Thunb. Antiviral Research 144, 273-280.

Meng, L., Lozano, Y., Bombarda, I., Gaydou, E., \& Li, B. (2006). Anthocyanin and flavonoid production from Perilla frutescens: Pilot plant scale processing including cross-flow microfiltration and reverse osmosis. Journal of Agricultural and Food Chemistry 54(12), 4297-4303.

Miyata, M., Koyama, T., \& Yazawa, K. (2010). Water extract of Houttuynia cordata Thunb. Leaves exerts anti-obesity effects by inhibiting fatty acid and glycerol absorption. Journal of Nutritional Science and Vitaminology 56(2), 150-156.
Myers, R. H., \& Montgomery, D. C. (2002). Response surface methodology: Product and process optimization using designed experiments ( $2^{\text {nd }}$ ed.). New York, USA: John Wiley \& Sons.

Puri, M, Sharma, D., \& Barrow, C. J., (2012). Enzymeassisted extraction of bioactives from plants. Trends in Biotechnology 30(1), 37-44.

Sekita, Y., Murakami, K., Yumoto, H., Mizuguchi, H., Amoh, T., Ogino, S., Matsuo, T., Miyake, Y., Fukui, H., \& Kashiwada, Y. (2016). Anti-bacterial and antiinflammatory effects of ethanol extract from Houttuynia cordata poultice. Bioscience Biotechnology and Biochemistry 80(6), 1205-1213.

Truong, D. H., Le Q. P. T., Tran C. T. H., Pham, N. T. K., \& Dong D. T. A. (2015). Optimization of extraction and extraction of crude saponins from Codonopsis Javanica (Blume) Hook. f. by alpha-amylase enzyme. Science and Technology Information Special 4(99), 13.

Vergara-Barberán, M., Lerma-García, M. J., HerreroMartínez, J. M., \& Simó-Alfonso, E. F. (2015). Use of an enzyme-assisted method to improve protein extraction from olive leaves. Food Chemistry 169, 28-33.

Verma, R. S., Joshi, N., Padalia, R. C., Singh, V. R., Goswami, P., Kumar, A., Iqbal, H., Verma, R. K., Chanda, D., Chauhan, A., \& Saikia, D. (2017). Chemical composition and allelopathic, antibacterial, antifungal, and antiacetylcholinesterase activity of fishmint (Houttuynia cordata Thunb.) from India. Chemistry \& Biodiversity 14(10), e1700189.

Wang, J. Y., Liu, Z. P., Liu, L., \& Liu, C. (2008). Effects of $\mathrm{NaCl}$ on the growth and alkaloid content of Catharanthus roseus seedlings. The Journal of Applied Ecology 19(10), 2143-2148. 